\title{
Penggunaan Path Analysis Dalam Analisis Pengaruh Efisiensi Operasional, Tingkat Kecukupan Modal Dan Likuiditas Terhadap Profitabilitas Bank Umum Syariah Di Indonesia Tahun 2011-2014
}

\author{
Ari Kristin Prasetyoningrum ${ }^{1 *}$, Siti Nur Hasanah ${ }^{2}$ \\ ${ }^{1}$ Fakultas Ekonomi dan Bisnis Islam, UIN Walisongo \\ ${ }^{2}$ Fakultas Ekonomi dan Bisnis Islam, UIN Walisongo \\ *Email corresponding author: ari.kristin@gmail.com
}

\begin{abstract}
Abstrak
Penelitian ini bertujuan untuk mengetahui apakah Biaya Operasional (BOPO), Tingkat Kecukupan Modal (CAR), dan Likuiditas (QR) berpengaruh terhadap Profitabilitas (ROA) Bank Umum Syariah Tahun 2011-2014 baik secara langsung maupun tidak langsung. Dalam penelitian ini penulis menggunakan metode penelitian kuantitatif. Sumber data yang digunakan adalah data sekunder berupa laporan keuangan triwulanan dari Bank Umum Syariah periode 2011-2014 yang diperoleh dari website resmi bank-bank terkait serta laporan keuangan triwulanan Bank Umum Syariah yang dipublikasikan oleh Bank Indonesia melalui website resmi. Analisis hipotesis menggunakan analisis jalur (path analysis)karena terdapat dua model persamaan (substruktur) dengan bantuan progam aplikasi IBM SPSS 21.00. dan menggunakan teknik purposive sampling berdasarkan kriteria tertentu untuk menentukan jumlah sampel penelitian. Sampel dalam penelitian ini adalah laporan keuangan triwulanan 7 Bank Syariah (BRI Syariah, Bank Syariah Mandiri, Bank Panin Syariah, BCA Syariah, Bank Mega Syariah, dan Maybank Syariah) periode 2011-2014, masing-masing bank sebanyak 16 laporan keuangan sehingga datanya berjumlah 112. Hasil penelitian ini menunjukkan bahwa Biaya Operasional (BOPO), Tingkat Kecukupan Modal (CAR), dan Likuiditas(QR) berpengaruh terhadap profitabilitas (ROA) secara langsung, dan secara berurutan. Selain itu terdapat pula pengaruh tidak langsung antara tingkat Kecukupan Modal (CAR) terhadap Profitabilitas (ROA) melalui Likuiditas (QR), dengan posisi Likuiditas (QR) sebagai pelemah dari pengaruh tersebut.
\end{abstract}

Kata kunci : Biaya Operasional (BOPO), Tingkat Kecukupan Modal (CAR), Dan Likuiditas (QR), Profitabilitas (ROA), Bank Syariah.

\begin{abstract}
This study was to determine the effect of Operating Costs (ROA), level of capital adequacy (CAR), and Liquidity (QR) to Profitability (ROA) at the Islamic Banks in 2011-2014. This study used quantitative research methods. Source of research data are secondary data from the quarterly financial statements of Islamic Banks in 2011 to 2014 were obtained from the website. This study using path analysis because there are two models of the equation (substructure) with IBM SPSS application program. Purposive sampling technique is used to determine number of sample. The sample was seventh quarterly financial statements Islamic Bank (BRI Syariah, Bank Syariah Mandiri, Bank Panin Syariah, BCA Syariah, Bank Mega Syariah, and Maybank Syariah) from 2011 to 2014, each bank was obtained 16 financial statements in order to obtain 112 data. The results of this study indicate that the Operating Costs (ROA), level of capital adequacy (CAR), and Liquidity (QR) had an influence on profitability (ROA). There are also indirect influence between the level of capital adequacy (CAR) to Profitability (ROA) through Liquidity (QR), the liquidity position (QR) as the weakening of the influence.
\end{abstract}

Keywords: Operating Costs (ROA), level of capital adequacy (CAR), and Liquidity (QR), profitability (ROA), Bank Syariah.

\footnotetext{
${ }^{1}$ Dosen Jurusan Akuntansi Syariah Fakultas Ekonomi dan Bisnis Islam UIN Walisongo Semarang

${ }^{2}$ Mahasiswa Jurusan Ekonomi Islam Fakultas Ekonomi dan Bisnis Islam UIN Walisongo Semarang
} 
Penggunaan Path Analysis Dalam Analisis.....

\section{PENDAHULUAN}

Kinerja keuangan suatu bank mencerminkan tingkat kesehatan bank. Dalam Surat Edaran BI No. 9/24/DPbs disebutkan penilaian tingkat kesehatan bank dipengaruhi oleh faktor CAMELS (Capital, Asset Quality, Management, Earnings, Liquidity, Sensitivity to Market Risk). Aspek Capital meliputi Kewajiban Penyediaan Modal Minimum (KPMM) atau Capital Adequacy Ratio (CAR), aspek Asset Quality meliputi Non Performing Financing (NPF), aspek Earnings meliputi Return On Equity (ROE), Return On Asset (ROA), dan Operational Efficiency Ratio (BOPO), Liquidity meliputi Current Ratio (CR) dan Quick Ratio (QR).Rasio Efisiensi Operasional (BOPO) mengindikasikan efisiensi operasional bank. Semakin tinggi rasio Efisiensi Operasional, menunjukkan semakin tidak efisien biaya operasional bank (Taswan, 2010). Semakin tinggi rasio Efisiensi Operasional (BOPO) berarti semakin buruk. Dengan demikian besar kecilnya Efisiensi Operasional akan mempengaruhi profitabilitas bank (ROA).

Rasio Kecukupan Modal (CAR) merupakan perbandingan modal bank dengan ATMR. Semakin tinggi rasio Kecukupan Modal mengindikasikan bank tersebut semakin sehat permodalannya. Pemenuhan Kecukupan Modal minimum 8\% mengindikasikan bank mematuhi regulasi permodalan (Taswan, 2010). Besarnya modal suatu bank akan berpengaruh pada mampu atau tidaknya suatu bank secara efisien menjalankan kegiatannya. Jika modal yang dimiliki oleh bank tersebut mampu menyerap kerugiankerugian yang tidak dapat dihindarkan, maka bank dapat mengelola seluruh kegiatannya secara efisien, sehingga kekayaan bank (kekayaan pemegang saham) diharapkan akan semakin meningkat demikian juga sebaliknya. Sehingga dapat disimpulkan bahwa hubungan antara kecukupan modal dengan profitabilitas (ROA) adalah positif.

Selain mempunyai hubungan positif dengan profitabilitas (ROA), Rasio Kecukupan Modal (CAR) juga mempunyai hubungan positif terhadap Rasio likuiditas karena semakin tinggi tingkat kecukupan modal (CAR) maka semakin tinggi pula tingkat likuiditas perbankan. Rasio Likuiditas menggambarkan kemampuan bank untuk menyelesaikan kewajiban jangka pendek. Rasio ini dapat dihitung melalui sumber informasi tentang modal kerja yaitu pos-pos aktiva lancar dan hutang lancar (Harahap, 2002), salah satunya yaitu dengan Rasio Cepat (Quick Ratio/QR). Quick Ratio (QR) yaitu rasio antara aktiva lancar terhadap hutang lancar. Semakin tinggi jumlah aktiva liquid maka semakin tinggi pula profitabilitas (ROA) perbankan.

Profitabilitas merupakan indikator yang paling tepat untuk mengukur kinerja suatu bank. Profitabilitas menggambarkan kemampuan perusahaan menghasilkan laba (Harahap, 2002). Salah satu rasio yang biasa digunakan untuk mengukur kinerja profitabilitas atau rentabilitas adalah Return On Asset (ROA). ROA menunjukkan kemampuan manajemen bank dalam menghasilkan income dari pengelolaan aset yang dimiliki (Yuliani, 2007). Berdasarkan pengertian tersebut dapat disimpulkan bahwa Return On Asset (ROA) fokus pada kemampuan perusahaan untuk memperoleh pendapatan dalam operasi perusahaan.

Alasan dipilihnya Return On Asset (ROA) sebagai ukuran kinerja adalah karena ROA digunakan untuk mengukur kemampuan manajemen bank dalam memperoleh keuntungan secara keseluruhan. Semakin tinggi rasionya, maka semakin baik pula dalam menggunakan asetnya (Musyaroftun, 2012). 
Tabel 1. Data Statistik Perbankan Umum Syariah

\begin{tabular}{ccccc}
\hline Indikator (\%) & $\mathbf{2 0 1 1}$ & $\mathbf{2 0 1 2}$ & $\mathbf{2 0 1 3}$ & $\mathbf{2 0 1 4}$ \\
\hline Efisiensi operasional (BOPO) & 78,41 & 74,97 & 78,21 & 79,28 \\
\hline Kecukupan modal (CAR) & 16,63 & 14,13 & 14,42 & 16,10 \\
\hline Likuiditas (QR) & 27,80 & 22,18 & 21,13 & 23,75 \\
\hline Profitabilitas (ROA) & 1,79 & 2,14 & 2,00 & 0,80 \\
\hline
\end{tabular}

Sumber : Statistik Rasio Keuangan Bank Umum Syariah Desember 2014 (diolah)

Tabel 2. Data Statistik Rasio Profitabilitas (ROA) Dan Rasio Efisiensi Operasional (BOPO) Bank Umum Syariah Tahun 2014

\begin{tabular}{ccccccccccccc}
\hline \hline \multicolumn{1}{c}{$\begin{array}{c}\text { Indikator } \\
(\%)\end{array}$} & Jan & Feb & Mar & Apr & Mei & Jun & Jul & Agus & Sep & Okt & Nov & Des \\
\hline ROA & 0,08 & 0,13 & 1,16 & 1,09 & 1,13 & 1,12 & 1,05 & 0,93 & 0,97 & 0,92 & 0,87 & 0,80 \\
\hline BOPO & 80,05 & 83,77 & 91,90 & 84,50 & 76,49 & 71,76 & 79,80 & 81,20 & 82,39 & 75,61 & 93.5 & 79,28 \\
\hline \hline
\end{tabular}

Tabel 1 dan 2 menunjukkan bahwa secara empiris rasio-rasio keuangan dari tahun ke tahun mengalami perubahan. Pada tabel 1 menunjukkan bahwa tahun 2011 rasio profitabilitas (ROA) pada Bank Umum Syariah adalah sebesar 1,79\% dengan tingkat kecukupan modal (CAR) sebesar 16,63\%. Sedangkan pada tahun 2012 rasio profitabilitas (ROA) mengalami kenaikan sebesar 0,35\% dengan tingkat kecukupan modal (CAR) yang mengalami penurunan sebesar 2,5\%. Pada tahun 2013 dan 2014 rasio profitabilitas kembali mengalami penurunan sebesar $0,14 \%$ dan 1,2\% sedangkan tingkat kecukupan modal (CAR) mengalami kenaikan sebesar 0,29\% dan 1,68\%. Dengan dmikian hal ini bersimpangan dengan teori yang menyatakan bahwa kecukupan modal (CAR) berpengaruh positif terhadap profitabilitas (ROA).

Pada tahun 2011 tingkat kecukupan modal (CAR) pada bank umum syariah adalah sebesar 16,63\% dengan rasio likuiditas (QR) sebesar 27,80\%. Pada tahun 2012 tingkat kecukupan modal (CAR) mengalami penurunan sebesar 2,5\% dengan rasio likuiditas yang juga mengalami penurunan sebesar 5,62\%. Akan tetapi pada tahun 2013 Rasio kecukupan modal mengalami kenaikan sebesar 0,29\% sedangkan rasio likuiditas justru mengalami penurunan kembali sebesar 1,05\%.

Pada tahun 2011 rasio likuiditas (QR) adala sebesar 27,80\% dengan tingkat profitabilitas 1,79\%. Pada tahun 2012 rasio Likuiditas (QR) mengalami penurunan sebesar 5,66\% dengan tingkat profitabilitas yang mengalami kenaikan sebesar 0,35\%. Pada tahun 2013 dan 2014 rasio likuiditas mengalami penurunan dan kenaikan sebasar $1,05 \%$ dan 2,62\% sedangkan tingkat profitabilitas selalu mengalami penurunan sebesar $0,14 \%$ dan $1,2 \%$.

Pada tabel 2 rasio efisiensi operasional (BOPO) pada bulan Mei tahun 2014 adalah sebesar 76,49\% dengan profitabilitas (ROA) sebesar 1,13\% yang kemudian di bulan Juni efisiensi operasional (BOPO) turun menjadi $71,76 \%$ dengan rasio profitabilitas (ROA) juga mengalami penurunan menjadi $1,12 \%$. Rasio efisiensi operasional (BOPO) pada bulan Agustus adalah sebesar 81,20\% dengan profitabilitas (ROA) sebesar $0,93 \%$ yang kemudian pada bulan September rasio efisiensi operasional (BOPO) mengalami kenaikan menjadi 82,39\%, dengan rasio profitabilitas (ROA) juga mengalami kenaikan menjadi 0,97\%. 
Kemudian pada bulan Oktober rasio efisiensi operasional (BOPO) mengalami penurunan menjadi 75,61\% dengan rasio profitabilitas (ROA) juga mengalami penurunan menjadi $0,92 \%$. Sehingga hal tersebut bersimpangan dengan teori yang menyatakan semakin tinggi rasio Efisiensi Operasional, menunjukkan semakin tidak efisien biaya operasional bank.

Dari fenomena gap di atas, dapat ditarik kesimpulan bahwa tidak semua kejadian empiris sesuai dengan teori yang ada. Hal ini diperkuat dengan adanya research gap dalam penelitian-penelitian terdahulu. Sebagai contoh penelitian yang dilakukan oleh Yuliani (2007) menunjukkan bahwa kecukupan modal (CAR) dan efisiensi operasional (BOPO) berpengaruh signifikan terhadap ROA. Sedangkan penelitian yang dilakukan oleh Edhi Satriyo Wibowo dan Muhammad Syaichu (2013) menunjukkan bahwa kecukupan modal (CAR) tidak memiliki pengaruh yang signifikan terhadap ROA, dan Efisiensi operasional (BOPO) memiliki pengaruh yang signifikan negatif terhadap ROA. Didukung oleh penelitian yang dilakukan oleh Dewi Inaroh (2014) yang menyatakan bahwa tidak ada pengaruh yang signifikan antara Kecukupan Modal (CAR) terhadap profitabilitas (ROA) dan terdapat pengaruh yang signifikan antara Efisiensi Operasional (BOPO) terhadap profitabilitas (ROA).

Penelitian yang dilakukan oleh Nidya Afrinda (2012) menunjukkan bahwa Quick Ratio (QR) secara parsial berpengaruh positif dan signifikan terhadap profitabilitas (ROA) yang didukung oleh penelitian yang dilakukan oleh Gemi Ruwanti (2011) yang menunjukkan bahwa Likuiditas berpengaruh secara parsial terhadap ROA. Sedangkan penelitian yang dilakukan oleh Nur Fadlila (2009) yang menunjukkan bahwa Variabel Likuiditas tidak terbukti berpengaruh terhadap perubahan Profitabilitas yang didukung oleh pendapat Rimski (2002) yang menyatakan semakin tinggi tingkat likuiditas berarti akan semakin banyak dana yang menganggur, semakin banyak uang yang menganggur berarti pemasaran uang tidak maksimal dan akhirnya bank tidak bisa memaksimalkan keuntungannya. Berdasarkan latar belakang di atas, maka perumusan masalah dalam penelitian ini adalah Apakah Efisiensi Operasional, Tingkat Kecukupan Modal, dan Likuiditas berpengaruh terhadap Profitabilitas Bank Umum Syariah di Indonesia tahun 2011-2014?

\section{BANK SYARIAH}

Menurut Undang-Undang No. 21 Tahun 2008 tentang Perbankan Syariah, Bank Syariah didefinisikan sebagai bank yang menjalankan kegiatan usahanya berdasarkan prinsip syariah dan menurut jenisnya terdiri atas Bank Umum Syariah dan Bank Pembiayaan Rakyat Syariah (Soemitra, 2009).Bank syariah merupakan bank yang dalam menjalankan usahanya berdasarkan pada prinsip-prinsip hukum atau syariah islam dengan mengacu kepada al-Qur'an dan al-Hadits (Rifai, 2002).

\section{EFISIENSI OPERASIONAL}

Efisiensi operasional merupakan kemampuan manajemen perbankan dalam mengendalikan biaya operasional terhadap pendapatan operasional(Andryani Isna K dan Kunti Sunaryo).Beban Operasional terhadap Pendapatan Operasional (BOPO). Rasio ini mengindikasikan efisiensi operasional bank. Semakin tinggi rasio ini menunjukkan semakin tidak efisien operasional bank(Taswan, 2010). Untuk menghitung rasio BOPO menggunakan rumus sebagai berikut: 


\section{BOPO $=\frac{\text { Biaya Operasional }}{\text { Pendapatan Operasional }} \times 100 \%$}

Adapun kriteria untuk menetukan peringkat efisiensi operasional bank syariah sesuai Surat Edaran Bank Indonesia No 13/24/DPNP, tanggal 25 oktober 2011, adalah sebagi berikut:

Tabel 3. Kriteria Penilaian Peringkat BOPO

\begin{tabular}{ccc}
\hline \hline Peringkat & Kriteria & Keterangan \\
\hline Peringkat 1 & $\mathrm{BOPO} \leq 83 \%$ & Sangat baik \\
\hline Peringkat 2 & $83 \%<\mathrm{BOPO} \leq 85 \%$ & Baik \\
\hline Peringkat 3 & $85 \%<\mathrm{BOPO} \leq 87 \%$ & Cukup baik \\
\hline Peringkat 4 & $87 \%<\mathrm{BOPO} \leq 89 \%$ & Kurang baik \\
\hline Peringkat 5 & $\mathrm{BOPO}>89 \%$ & Lemah \\
\hline
\end{tabular}

Sumber : Lampiran Surat Edaran BI

Masalah efisiensi berkaitan dengan masalah pengendalian biaya. Efisiensi operasional berarti biaya yang dikeluarkan untuk menghasilkan keuntungan lebih kecil daripada keuntungan yang diperoleh dari penggunaan aktiva tersebut. Bank yang dalam kegiatan usahanya tidak efisien akan mengakibatkan ketidakmampuan bersaing dalam mengerahkan dana masyarakat maupun dalam menyalurkan dana tersebut kepada masyarakat yang membutuhkan sebagai modal usaha. Dengan adanya efisiensi pada lembaga perbankan terutama efisiensi biaya maka akan diperoleh tingkat keuntungan yang optimal, penambahan jumlah dana yang disalurkan, biaya lebih kompetitif, peningkatan pelayanan kepada nasabah, keamanan dan kesehatan perbankan yang meningkat.

\section{Kecukupan Modal (Capital Adequancy Ratio / CAR)}

Kecukupan modal(CAR) adalah rasio yang memperlihatkan seberapa besar jumlah seluruh aktiva bank yang mengandung unsur risiko (pembiayaan, penyertaan, surat berharga, tagihan pada bank lain) yang ikut dibiayai dari modal sendiri disamping memperoleh dana-dana dari sumber-sumber diluar bank (Yuliani, 2007). Rasio Kecukupan modal (CAR) merupakan perbandingan modal bank dengan ATMR. Semakin tinggi rasio kecukupan modal mengindikasikan bank tersebut semakin sehat permodalannya. Pemenuhan kecukupan modal minimum 8\% mengindikasikan bank mematuhi regulasi permodalan (Taswan, 2010).

\begin{tabular}{cc}
$\begin{array}{c}\text { Tabel 4. Kriteria Penilaian Peringkat Kecukupan } \\
\text { Modal (CAR) }\end{array}$ \\
\hline Peringkat & Kriteria \\
\hline Peringkat 1 & $\mathrm{KPMM} \geq 12 \%$ \\
\hline Peringkat 2 & $9 \% \leq \mathrm{KPMM}<12 \%$ \\
\hline Peringkat 3 & $8 \% \leq \mathrm{KPMM}<9 \%$ \\
\hline Peringkat 4 & $6 \%<\mathrm{KPMM}<8 \%$ \\
\hline Peringkat 5 & $\mathrm{KPMM} \leq 6 \%$ \\
\hline Sumber : Lampiran Surat Edaran $\mathrm{BI}$
\end{tabular}

Rumus perhitungan CAR adalah :

$$
\text { CAR }=\frac{\text { Modal Bank }}{\text { ATMR }} \times 100 \%
$$


Penggunaan Path Analysis Dalam Analisis.....

\section{Likuiditas (Liquidity)}

Rasio likuiditas merupakan rasio yang menunjukkan kemampuan perusahaan untuk memenuhi kewajiban jangka pendek (lebih besar lebih baik). Rasio likuiditas bank merupakan rasio yang digunakan untuk mengukur kemampuan bank dalam memenuhi kewajiban jangka pendeknya pada saat ditagih. Dengan kata lain, bank dapat membayar kembali pencairan dana para deposannya pada saat di tagih serta dapat mencukupi permintaan pembiayaan yang telah diajukan(Kasmir, Analisis Laporan Keuangan, 2008).

Semakin besar rasio ini, maka semakin likuid. Rasio ini dapat dihitung melalui sumber informasi tentang modal kerja yaitu pos-pos aktiva lancar dan hutang lancar salah satunya melalui Rasio Cepat (Quick Ratio/QR). Untuk menilai baik atau buruknya likuiditas sebuah perbankan itu terdapat sebuah standar minimal yang dinyatakan dalam angka atau dapat juga dibandingkan dengan perusahaan sejenis maupun dibandingkan dengan nilai nominal likuiditas pada periode sebelumnya dari perbankan tersebut.

Quick Ratio (QR) merupakan rasio untuk mengukur kemampuan bank dalam memenuhi kewajibannya terhadap para deposan (pemilik simpanan giro, tabungan, dan deposito) dengan harta yang paling likuid yang dimiliki oleh suatu bank(Kasmir, Analisis Laporan Keuangan, 2008). QR menunjukkan kemampuan aktiva lancar yang paling likuid mampu menutupi hutang lancar. Rasio ini disebut juga Acid Test Ratio. Angka ratio ini tidak harus 100\% atau 1:1(Harahap, 2002).

Tabel 5. Kriteria Penilaian Peringkat Quick Ratio (QR)

\begin{tabular}{cc}
\hline \hline Peringkat & Kriteria \\
\hline Sehat & $=>4,05 \%$ \\
\hline Cukup sehat & $3,30 \%-4,04 \%$ \\
\hline Kurang Sehat & $2,55 \%-3,29 \%$ \\
\hline Tidak Sehat & $<2,55 \%$ \\
\hline \hline \multirow{2}{*}{$\begin{array}{c}\text { Sumber : Ratno Agriyanto, S.Pd. Akt. M. Si. CA., Modul } \\
\text { praktikum Analisa Laporan Keuangan, } 2015\end{array}$}
\end{tabular}

Untuk menghitung Quick Ratio yaitu dengan rumus sebagai berikut:

$$
\text { Quick Ratio }(Q R)=\frac{\text { Quick Asset }}{\text { Hutang Lancar }} \times 100 \%
$$

\section{Profitabilitas (Profitability)}

Profitabilitas merupakan rasio yang menunjukkan sejauh mana perusahaan mampu menghasilkan laba (lebih besar lebih baik). Profitabilitas juga bisa dikatakan sebagai kemampuan suatu perusahaan untuk menghasilkan laba dari aktivitas operasinya yang dihasilkan dari kegiatan usahanya selama periode tertentu. Menurut Lukman seperti yang dikutip oleh Defri mendefinisikan profitabilitas sebagai kemampuan bank untuk menghasilkan/memperoleh laba secara efektif dan efisien (Defri). Rasio profitabilitas mengukur kemampuan perusahaan menghasilkan keuntungan (profitabilitas) pada tingkat penjualan, aset dan modal saham yang tertentu (Mamduh M. Hanafi dan Abdul Halim, 2009).

Ada dua rasio yang biasanya dipakai untuk mengukur profitabilitas bank yaitu Return On Asset (ROA) dan Return On Equity (ROE). ROA adalah perbandingan antara pendapatan bersih (net income) dengan rata-rata aktiva (average assets). ROE didefinisikan sebagai perbandingan antara pendapatan bersih (net income) dengan rata-rata modal (average equity) atau investasi pemilik bank. Dari pandangan 
pemilik, ROE adalah ukuran yang lebih penting karena merefleksikan kepentingan kepemilikan mereka (Arifin, 2003).

ROA merupakan rasio yang mengukur kemampuan perusahaan menghasilkan laba bersih berdasarkan tingkat aset yang tertentu. ROA sering disebut juga sebagai Return On Investment (ROI). Rasio yang tinggi menunjukkan efisiensi manajemen aset, yang berarti efisiensi manajemen(Mamduh M. Hanafi dan Abdul Halim, 2009).

Penentuan tingkat kesehatan suatu bank, Bank Indonesia lebih mementingkan penilaian ROA daripada ROE karena Bank Indonesia lebih mengutamakan nilai profitabilitas suatu bank yang diukur dengan asset yang dananya sebagian besar berasal dari dana simpanan masyarakat sehingga ROA lebih mewakili dalam mengukur tingkat profitabilitas perbankan. Semakin besar ROA suatu bank, semakin besar pula tingkat keuntungan yang dicapai bank tersebut dan semakin baik pula posisi bank tersebut dari segi penggunaan asset(Defri). Untuk mengukur ROA menggunakan rumus sebagai berikut:

$$
\text { ROA }=\frac{\text { Laba Bersih }}{\text { Asset }} \times 100 \%
$$

Adapun kriteria penilaian ROA menurut Surat Edaran Bank Indonesia No 13/24/DPNP, tanggal 25 oktober 2011, tentang sistem penilaian tingkat kesehatan Bank Umum berdasarkan Prinsip Syariah adalah sebagai berikut:

Tabel 6. Kriteria Penilaian Peringkat (ROA)

\begin{tabular}{lll}
\hline \multicolumn{1}{c}{ Peringkat } & \multicolumn{1}{c}{ Kriteria } & \multicolumn{1}{c}{ Keteranagan } \\
\hline Peringkat 1 & $\mathrm{ROA}>1,5 \%$ & Sangat baik \\
\hline Peringkat 2 & $1,25 \%<\mathrm{ROA} \leq 1,5 \%$ & Baik \\
\hline Peringkat 3 & $0,5 \%<\mathrm{ROA} \leq 1,25 \%$ & Cukup baik \\
\hline Peringkat 4 & $0 \%<\mathrm{ROA} \leq 0,5 \%$ & Kurang baik \\
\hline Peringkat 5 & $\mathrm{ROA} \leq 0 \%$ & Lemah \\
\hline \hline Sumber : Lampiran Surat Edaran BI
\end{tabular}

\section{KERANGKA PEMIKIRAN TEORITIK}

Model konseptual yang didasarkan pada tinjauan pustaka, maka kerangka pemikiran teoritik penelitian di jelaskan pada gambar berikut:

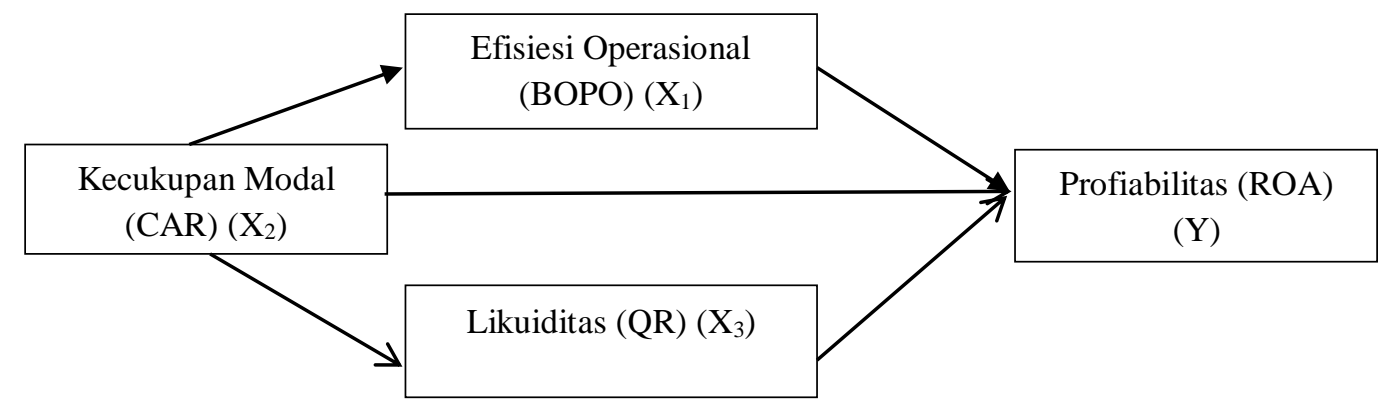

Gambar 1. Kerangka Pemikiran Teoritik

Berdasarkan tinjauan pustaka dan kerangka teori maka hipotesis penelitian dirumuskan sebagai berikut: 
$\mathrm{H}_{1}$ : Efisiensi Operasional (BOPO) berpengaruh secara signifikan terhadap Profitabilitas (ROA) Bank Umum Syariah

$\mathrm{H}_{2}$ Tingkat Kecukupan Modal (CAR) berpengaruh secara signifikan terhadap Profitabilitas (ROA) Bank Umum Syariah

$\mathrm{H}_{3}$ Likuiditas (QR) berpengaruh secara signifikan terhadap Profitabilitas (ROA) Bank Umum Syariah.

$\mathrm{H}_{4}$ Tingkat Kecukupan Modal (CAR) berpengaruh secara signifikan terhadap Profitabilitas melaluiLikuiditas (QR) Bank Umum Syariah

\section{METODE PENELITIAN}

Jenis penelitian ini adalah penelitian kausalitas. Sumber data yang digunakan dalam penelitian ini adalah data sekunder berupa laporan keuangan triwulanan dari Bank Umum Syariah periode 2011-2014 yang diperoleh dari website resmi bank serta laporan keuangan triwulanan Bank Umum Syariah yang dipublikasikan oleh Bank Indonesia melalui website resmi. Jenis data ini merupakan Data Cross Section (Data silang) dari beberapa lembaga perbankan. Populasi yang di gunakan dalam penelitian ini adalah laporan keuangan triwulanan bank-bank syariah yang resmi terdaftar di Bank Indonesia yang sampai saat ini ada 11 bank syariah yang terdaftar. Teknik sampling yang digunakan dalam penelitian ini adalah purposive sampling yaitu teknik penentuan sampel dengan pertimbangan tertentu (Sugiyono, 2012) sehingga diperoleh jumlah sampel sebanyak 112 laporan keuangan, dengan rincian 16 laporan keuangan Bank Syariah BRI, 16 laporan keuangan Bank Syariah Mandiri, 16 laporan keuangan Bank BNI Syariah, 16 laporan keuangan Bank BCA Syariah, 16 laporan keuangan Bank Panin Syariah, 16 laporan keuangan Bank Mega Syariah dan 16 laporan keuangan Maybank Syariah. Beberapa kriteria yang ditetapkan untuk memperoleh sampel adalah bank yang diteliti masih beroperasi pada periode waktu penelitian dan tersedia laporan keuangan triwulanan secara lengkap pada periode 2011

Teknik analisis yang digunakan dalam penelitian ini adalah analisis statistik deskriptif dan model kausalitas, sehingga untuk menguji hipotesis, alat analisis yang dipergunakan adalah model path analysis (Analisis Jalur). Analisis path dalam penelitian ini menggunakan bantuan program aplikasi statistik IBM SPSS 21.00. sedangkan untuk menguji kualitas data digunakan uji Uji asumsi klasik.

\section{ANALISIS DATA DAN PEMBAHASAN}

Hasil Statistik Deskriptif

Tabel 7. Descriptive Statistik ROA, BOPO, CAR, dan QR

\begin{tabular}{|c|c|c|c|c|c|c|c|c|c|c|c|}
\hline & \multirow{2}{*}{$\begin{array}{c}\mathrm{N} \\
\text { Stati } \\
\text { stic }\end{array}$} & \multirow{2}{*}{$\begin{array}{l}\begin{array}{c}\text { Mini } \\
\text { mum }\end{array} \\
\text { Stati } \\
\text { stic }\end{array}$} & \multirow{2}{*}{$\begin{array}{l}\text { Maxim } \\
\text { um } \\
\text { Statist } \\
\text { ic }\end{array}$} & \multicolumn{2}{|c|}{ Mean } & \multirow{2}{*}{$\begin{array}{c}\text { Std. } \\
\text { Deviation }\end{array}$} & \multirow{2}{*}{$\begin{array}{l}\text { Variance } \\
\text { Statistic }\end{array}$} & \multicolumn{2}{|c|}{ Skewness } & \multicolumn{2}{|c|}{ Kurtosis } \\
\hline & & & & Statistic & $\begin{array}{l}\text { Std. } \\
\text { Error }\end{array}$ & & & $\begin{array}{l}\text { Stati } \\
\text { stic }\end{array}$ & $\begin{array}{c}\text { Std. } \\
\text { Erro } \\
\text { r }\end{array}$ & $\begin{array}{l}\text { Stati } \\
\text { stic }\end{array}$ & $\begin{array}{l}\text { Std. } \\
\text { Error }\end{array}$ \\
\hline ROA (Y) & 112 & $-2,63$ & 5,61 & 1,6604 & 12070, & 1,27737 & 1,632 & 335 & 228 & $\begin{array}{c}1,20 \\
9\end{array}$ & ,453 \\
\hline BOPO (X1) & 112 & $\begin{array}{c}50,7 \\
6 \\
\end{array}$ & $\begin{array}{c}134,1 \\
0\end{array}$ & 82,1615 & 1,25386 & 13,26960 & 176,082 & 168 & ,228 & $\begin{array}{c}1,42 \\
5\end{array}$ & ,453 \\
\hline CAR (X2) & 112 & $\begin{array}{c}11,0 \\
6\end{array}$ & $\begin{array}{c}121,8 \\
9\end{array}$ & 30,3359 & 2,27362 & 24,06170 & 578,965 & $\begin{array}{c}1,72 \\
6 \\
\end{array}$ & 228 & $\begin{array}{c}2,65 \\
9 \\
\end{array}$ & ,453 \\
\hline
\end{tabular}




\begin{tabular}{cccccccccccc}
\hline QR (X3) & 112 & 6,61 & $\begin{array}{c}291,0 \\
4\end{array}$ & 56,7357 & 4,05143 & 42,87626 & 1838,374 & 2,09 & 228 & 7,54 & 2 \\
2 & 453 \\
\hline $\begin{array}{c}\text { Valid N } \\
\text { listwise) }\end{array}$ & 112 & & & & & & & & & & \\
\hline \hline
\end{tabular}

Sumber: Data Sekunder Diolah

Berdasarkan tabel diatas menunjukkan bahwa dari periode Juni 2009 sampai Januari 2015 diperoleh hasil rata-rata ROA Bank Syariah sebesar 1,6604. Pencapaian tertinggi sebesar 5,61 yang terjadi pada bulan maret 2014 pada Maybank Syariah. Sedangkan pencapaian terendah dari pendapatan bank sebesar -2,63 yang terjadi pada bulan Januari 2015 pada Maybank Syariah. Standar deviasi sebesar 1,27737. Hasil tampilan output SPSS memberikan nilai skewness sebasar 0,335 sehingga dapat disimpulkan bahwa data ROA terdistribusi secara normal karena nilai kurang dari satu. Sedangkan nilai kurtosis adalah 1,425 sehingga dapat disimpulkan bahwa data ROA terdistribusi secara tidak normal karena lebih dari satu.

Pada periode Maret 2011 sampai Desember 2014 diperoleh hasil rata-rata BOPO Bank Syariah sebesar 82,1615. Pencapaian tertinggi sebesar 134,10 yang terjadi pada bulan maret 2011 pada Bank Panin Syariah. Sedangkan pencapaian terendah dari BOPO sebesar 50,76 yang terjadi pada bulan Desember 2012 pada Bank Panin Syariah. Standar deviasi sebesar 13,26960. Hasil tampilan output SPSS memberikan nilai skewness sebesar 0,168 sehingga dapat disimpulkan bahwa data BOPO terdistribusi secara normal karena nilai kurang dari satu. Sedangkan nilai kurtosis adalah 1,425 sehingga dapat disimpulkan bahwa data BOPO terdistribusi secara tidak normal karena lebih dari satu.

Pada periode maret 2011 sampai Desember 2014 diperoleh hasil rata-rata CAR Bank Syariah sebesar 30,3359. Pencapaian tertinggi sebesar 121,89 yang terjadi pada bulan maret 2011 pada Maybank Syariah. Sedangkan pencapaian terendah CAR bank sebesar 11,06 yang terjadi pada bulan September 2011 pada Bank Syariah Mandiri. Standar deviasi sebesar 24,06170. Hasil tampilan output SPSS memberikan nilai skewness dan kurtosis masing-masing 1,726 dan 2,659 sehingga dapat disimpulkan bahwa data CAR terdistribusi secara tidak normal karena nilai masing-masing lebih dari satu.

Pada periode maret 2011 sampai Desember 2014 diperoleh hasil rata-rata QR Bank Syariah sebesar 56,7357. Pencapaian tertinggi sebesar 291,04 yang terjadi pada bulan Desember 2011 pada Bank BNI Syariah. Sedangkan pencapaian terendah QR bank sebesar 6,61 yang terjadi pada bulan Juni 2014 pada Bank Mega Syariah. Standar deviasi sebesar 42,87626. Hasil tampilan output SPSS memberikan nilai skewness dan kurtosis masing-masing 2,098 dan 7,542 sehingga dapat disimpulkan bahwa data QR terdistribusi secara tidak normal karena nilai masing- masing lebih dari satu.

\section{Hasil Model Kausalitas}

Model kausalitas merupakan hubungan/pengaruh sebab akibat antar variabel, sehingga untuk menguji hipotesis, alat analisis yang dipergunakan adalah model path analysis (Analisis Jalur). dengan langkahlangkah sebagai berikut (i) mencari konstribusi dari variabel BOPO (X1), CAR (X2), dan QR (X3) terhadap ROA $(\mathrm{Y})$ dengan program regresi ganda linear (multiple regression linier), dimana kolom dependent dimasukkan Y dan kolom independent dimasukkan X1, X2, dan X3 (Substruktur 1). Dalam perhitungan kita pilih analisis correlate, bivariate dengan memasukkan ketiga variabel independen ke kolom variable. 
Tabel 8. Model Summary Variabel BOPO, CAR, dan QR terhadap ROA

\begin{tabular}{lrrrrr}
\hline Model & $\mathrm{R}$ & $\mathrm{R}$ Square & $\begin{array}{c}\text { Adjusted R } \\
\text { Square }\end{array}$ & $\begin{array}{c}\text { Std. Error of the } \\
\text { Estimate }\end{array}$ \\
\hline 1 &, $683^{\mathrm{a}}$ &, 466 &, 451 &, 94612 \\
\hline \hline a. Predictors: (Constant), QR (X3), BOPO (X1), CAR (X2) &
\end{tabular}

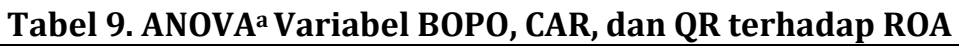

\begin{tabular}{llrrrrr}
\hline Model & & $\begin{array}{c}\text { Sum of } \\
\text { Squares }\end{array}$ & Df & \multicolumn{1}{c}{$\begin{array}{c}\text { Mean } \\
\text { Square }\end{array}$} & F & Sig. \\
\hline \multirow{3}{*}{1} & Regression & 84,438 & 3 & 28,146 & 31,443 &, $000^{\mathrm{b}}$ \\
\cline { 2 - 7 } & Residual & 96,676 & 108 &, 895 & & \\
\cline { 2 - 7 } & Total & 181,115 & 111 & & & \\
\hline \hline
\end{tabular}

a. Dependent Variable: ROA (Y)

b. Predictors: (Constant), QR (X3), BOPO (X1), CAR (X2)

Tabel 10. Coefficients ${ }^{a}$ Variabel BOPO, CAR, dan QR terhadap ROA

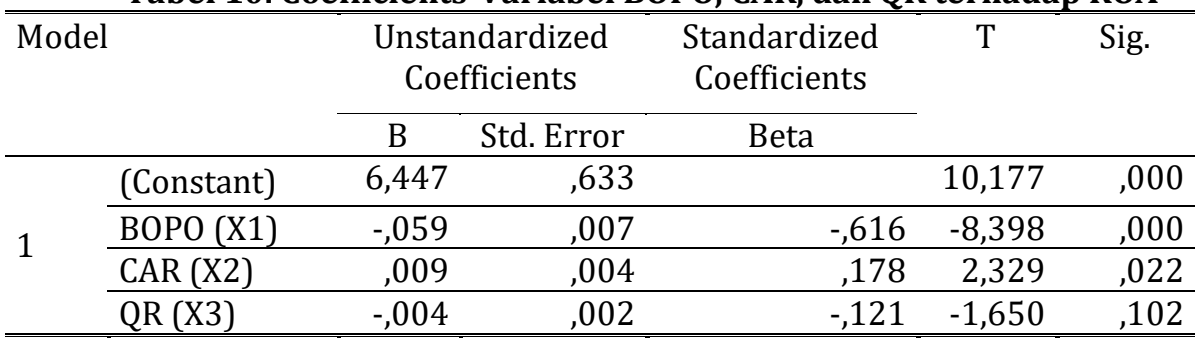

a. Dependent Variable: ROA (Y)

b.

Tabel 11. Correlations Variabel BOPO, CAR, dan QR terhadap ROA

\begin{tabular}{llrrr}
\hline \hline & & BOPO $(X 1)$ & CAR $(X 2)$ & QR $(X 3)$ \\
\hline \multirow{2}{*}{ BOPO (X1) } & Pearson Correlation & 1 &,$- 282^{* *}$ &,- 056 \\
\cline { 2 - 5 } & Sig. (2-tailed) & 112 &, 003 &, 559 \\
\cline { 2 - 5 } N & Pearson Correlation &,$- 282^{* *}$ & 112 & 112 \\
\cline { 2 - 5 } CAR (X2) & Sig. (2-tailed) &, 003 & &, 002 \\
\cline { 2 - 5 } & $\mathrm{N}$ & 112 & 112 & 112 \\
\hline \multirow{3}{*}{ QR (X3) } & Pearson Correlation &,- 056 &, $294^{* *}$ & 1 \\
\cline { 2 - 5 } & Sig. (2-tailed) &, 559 &, 002 & \\
\cline { 2 - 5 } & $\mathrm{N}$ & 112 & 112 & 112 \\
\hline \hline
\end{tabular}

**. Correlation is significant at the 0.01 level (2-tailed).

a. Mencari konstribusi dari variabel CAR (X2) melalui QR (X3) terhadap ROA (Y)dengan program regresi sederhana.

Tabel 12. Coefficients ${ }^{\mathrm{a}}$ variabel CAR melalui QR

\begin{tabular}{|c|c|c|c|c|c|c|}
\hline \multirow{2}{*}{\multicolumn{2}{|c|}{ Model }} & \multicolumn{2}{|c|}{$\begin{array}{c}\text { Unstandardized } \\
\text { Coefficients } \\
\end{array}$} & \multirow{2}{*}{$\begin{array}{c}\begin{array}{c}\text { Standardized } \\
\text { Coefficients }\end{array} \\
\text { Beta } \\
\end{array}$} & \multirow[t]{2}{*}{$\mathrm{T}$} & \multirow[t]{2}{*}{ Sig. } \\
\hline & & B & Std. Error & & & \\
\hline \multirow{2}{*}{1} & (Constant) & 40,834 & 6,277 & & 6,506 & , 000 \\
\hline & CAR (X2) &, 524 & ,162 & 294 & 3,228 & 002 \\
\hline
\end{tabular}

a. Dependent Variable: QR (X3)

(ii) menyelesaikan substruktur kedua untuk melihat kontribusi CAR (X2) dan QR (X3) terhadap ROA (Y), baik secara langsung maupun tidak langsung. Langkah penyelesaian hampir sama dengan langkah 
pertama dalam entri data. Jika data telah dimasukkan dan diperintah analisis dengan multiple regresion linier.

Tabel 13. Model Summary variabel CAR dan QR terhadap ROA

\begin{tabular}{lcccc}
\hline \hline Model & $\mathrm{R}$ & R Square & $\begin{array}{c}\text { Adjusted R } \\
\text { Square }\end{array}$ & $\begin{array}{c}\text { Std. Error of the } \\
\text { Estimate }\end{array}$ \\
\hline 1 &, $343^{\mathrm{a}}$ &, 118 &, 101 & 1,21085 \\
\hline \hline a. Predictors: (Constant), QR (X3), CAR (X2) & &
\end{tabular}

Tabel 14. ANOVAa variabel CAR dan QR terhadap ROA

\begin{tabular}{llcrcrc}
\hline \hline Model & & $\begin{array}{c}\text { Sum of } \\
\text { Squares }\end{array}$ & Df & $\begin{array}{c}\text { Mean } \\
\text { Square }\end{array}$ & F & Sig. \\
\hline \multirow{3}{*}{1} & $\begin{array}{l}\text { Regressio } \\
\mathrm{n}\end{array}$ & 21,303 & 2 & 10,651 & 7,265 &, $001^{\mathrm{b}}$ \\
\cline { 2 - 7 } & Residual & 159,812 & 109 & 1,466 & & \\
\cline { 2 - 7 } & Total & 181,115 & 111 & & & \\
\hline \hline
\end{tabular}

a. Dependent Variable: ROA (Y)

b. Predictors: (Constant), QR (X3), CAR (X2)

Tabel 15. Coefficients ${ }^{\mathrm{a}}$ variabel CAR dan QR terhadap ROA

\begin{tabular}{|c|c|c|c|c|c|c|}
\hline \multicolumn{2}{|c|}{ Model } & \multicolumn{2}{|c|}{$\begin{array}{l}\text { Unstandardized } \\
\text { Coefficients }\end{array}$} & \multirow{2}{*}{$\begin{array}{c}\text { Standardized } \\
\text { Coefficients } \\
\text { Beta }\end{array}$} & \multirow[t]{2}{*}{$\mathrm{T}$} & \multirow[t]{2}{*}{ Sig. } \\
\hline & & B & Std. Error & & & \\
\hline \multirow{3}{*}{1} & (Constant) & 1,322 & ,217 & & 6,083 & ,000 \\
\hline & CAR (X2) & 019 & ,005 & ,357 & 3,792 & , 000 \\
\hline & QR (X3) &,- 004 & ,003 &,- 140 & $-1,484$ & ,141 \\
\hline
\end{tabular}

a. Dependent Variable: ROA (Y)

Tabel 16. Correlations variabel CAR dan QR terhadap ROA

\begin{tabular}{llcc}
\hline \hline & & CAR (X2) & QR (X3) \\
\hline \multirow{3}{*}{ CAR (X2) } & \multicolumn{1}{l}{ Pearson Correlation } & 1 &, $294^{* *}$ \\
\cline { 2 - 4 } & \multicolumn{1}{l}{ Sig. (2-tailed) } & \multicolumn{1}{c}{002} \\
\cline { 2 - 4 } & $\mathrm{N}$ & 112 & 112 \\
\hline \multirow{3}{*}{ QR (X3) } & Pearson Correlation &, $294^{* *}$ & 1 \\
\cline { 2 - 4 } & Sig. (2-tailed) &, 002 & \\
\cline { 2 - 4 } & $\mathrm{N}$ & 112 & 112 \\
\hline \hline
\end{tabular}

**. Correlation is significant at the 0.01 level (2-tailed).

(iii) mencari pengaruh langsung dan tidak langsung serta pengaruh total dari variabel eksogen (independent) ke variabel indogen (dependent).Pengaruh langsung (direct effect) dari masing-masing variabel eksogen terhadap variabel indogen. Angka-angka pengaruh langsung adalah besaran $\beta$ pada tabel Coefficients, baik pada tahap pertama mauun tahap ke dua. Berdasarkan tabel Coefficients diatas dapat di simpulkan sebagai berikut: pengaruh variabel BOPO terhadap ROA sama dengan $-0,616$, pengaruh variabel CAR terhadap ROA 0,178, pengaruh variabel QR terhadap ROA -0,121, pengaruh variabel CAR melalui QR0,294, pengaruh tidak langsung antara variabel eksogen dengan indogen yaitu pengaruh variabel CAR terhadap ROA melalui QR yaitu -0,04116, pengaruh total (Total Effect) yaitu pengaruh variabel CAR terhadap ROA melalui QR sebesar 0,154.

\section{Uji Kualitas Data}

Dalam menguji kualitas data yang digunakan untuk penelitian, peneliti menggunakan Uji asumsi klasik antara lain: 
Penggunaan Path Analysis Dalam Analisis.....

Uji Normalitas. Uji normalitas dalam penelitian ini menggunakan analisis grafik Histogram dan Normal PP Plot Of Regressions Standardized Residual.

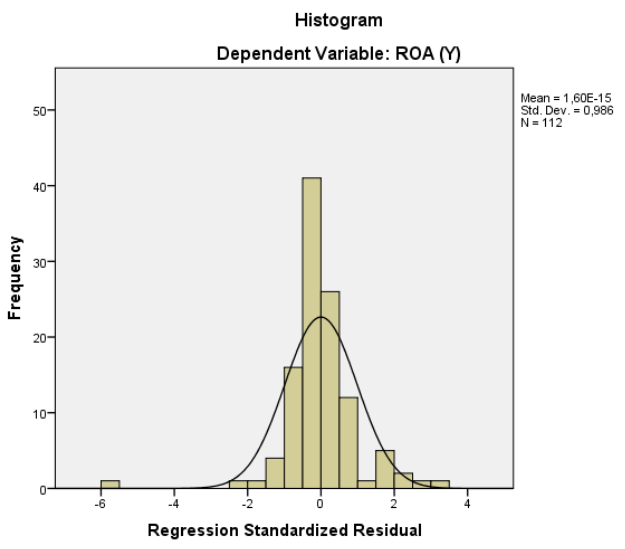

Gambar 2. Grafik Histogram Sumber: Data Sekunder Diolah

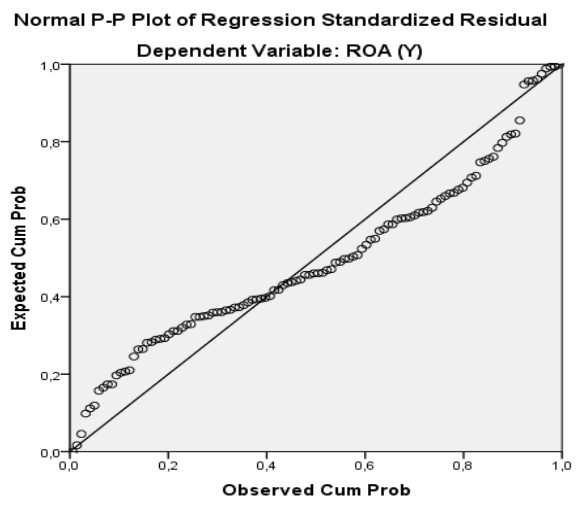

Gambar 3. Normal P-P Plot Of Regressions Standardized Residual

Sumber: Data Sekunder Diolah

Dari grafik histrogram atau grafik normal diatas terlihat bahwa residual terdistribusi secara normal dan berbentuk simetris tidak menceng ke kanan atau ke kiri. Pada grafik normal probility plots terlihat bahwa titik-titik menyebar diatas maupun bawah angka 0 pada sumbu $Y$.

Uji Multikolonieritas. Model regresi yang baik tidak terjadi korelasi diantara variabel independen.

Tabel 17. Uji Multikolonieritas dengan VIF dan Tolerance Coefficients $^{\mathrm{a}}$

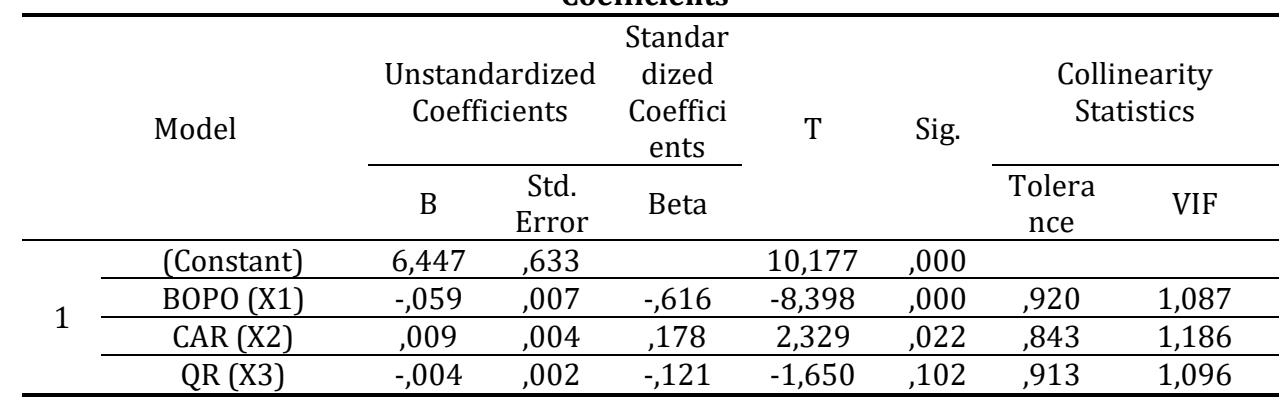

a. Dependent Variable: ROA (Y)

Sumber : Data Sekunder Diolah 
Hasil perhitungan nilai VIF untuk variabel BOPO (X1), CAR (X2) dan QR (X3) juga menunjukkan hal yang sama tidak ada satu variabel bebas yang memiliki nilai VIF lebih dari 10. Jadi dapat disimpulkan tidak ada multikolonieritas antar variabel independen dalam regresi.

Uji Autokorelasi. Pengujian adanya autokorelasi dilakukan dengan uji Durbin Watson (DW test).

\section{Tabel 18. Uji Autokorelasi dengan D-W test} Model Summaryb

\begin{tabular}{|c|c|c|c|c|c|}
\hline Model & $\mathrm{R}$ & R Square & $\begin{array}{l}\text { Adjusted R } \\
\text { Square }\end{array}$ & $\begin{array}{l}\text { Std. Error of } \\
\text { the Estimate }\end{array}$ & $\begin{array}{l}\text { Durbin- } \\
\text { Watson }\end{array}$ \\
\hline 1 & ,683a & ,466 & , 451 & 94612, & 1,268 \\
\hline
\end{tabular}

Sumber: Data Sekunder Diolah

Dari tabel diatas diketahui bahwa nilai D-W adalah sebesar 1,268 yang berarti nilai D-W diantara -2 sampai +2 sehingga dapat disimpulkan bahwa tidak ada autokorelasi.

Uji Heteroskedastisitas. Model regresi yang baik adalah jika tidak terjadi heteroskedastisitas.

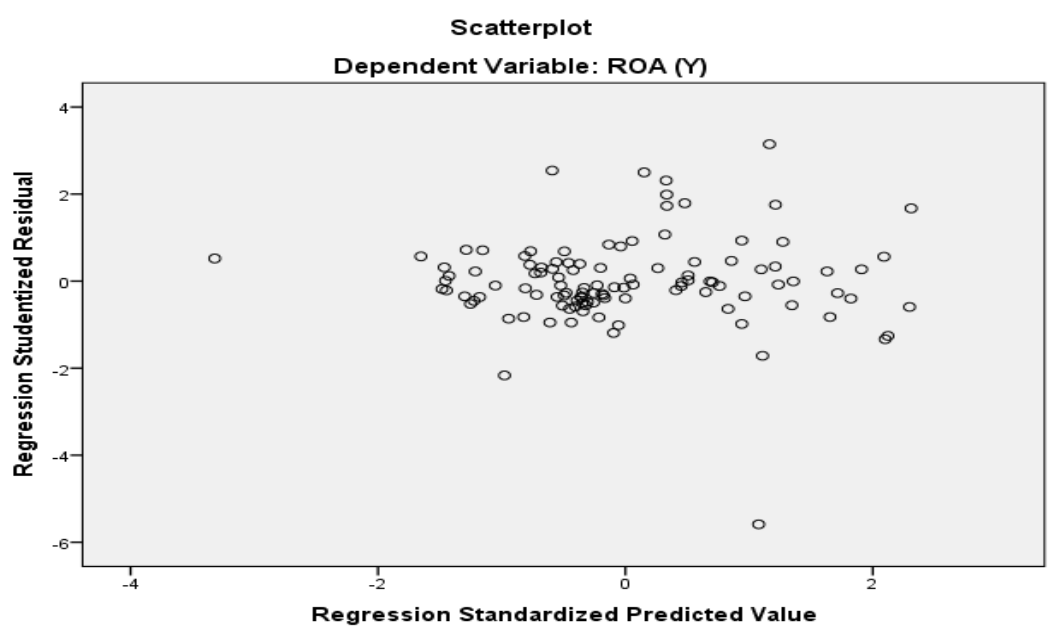

Gambar 4. Uji Heteroskedastisitas dengan Scatterplot

Dari grafik scatterplot terlihat bahwa titik-titik menyebar secara acak serta baik diatas maupun dibawah angka 0 pada sumbu y. Hal ini dapat disimpulkan bahwa penelitian ini tidak terjadi heteroskedastisitas

\section{Uji Hipotesis}

\section{Analisis Regresi Linear Berganda}

Analisis ini bertujuan untuk mengetahui apakah ada pengaruh antara Biaya Operasional (BOPO), Tingkat Kecukupan Modal (CAR) dan Likuidias (QR) terhadap Profitabilitas (ROA) pada bank umum syariah tahun 2011 - 2014. Pengolahan data menggunakan bantuan program komputer IBM SPSS versi 21.00. Berdasarkan data-data yang diperoleh dari laporan keuangan. 
Tabel 19. Uji Hipotesis Substruktur 1

Coefficients $^{\mathrm{a}}$

\begin{tabular}{|c|c|c|c|c|c|c|}
\hline & \multirow[t]{2}{*}{ Model } & \multicolumn{2}{|c|}{$\begin{array}{l}\text { Unstandardized } \\
\text { Coefficients }\end{array}$} & \multirow{2}{*}{$\begin{array}{c}\begin{array}{c}\text { Standardize } \\
\mathrm{d}\end{array} \\
\text { Coefficients } \\
\text { Beta }\end{array}$} & \multirow[t]{2}{*}{$\mathrm{T}$} & \multirow[t]{2}{*}{ Sig. } \\
\hline & & B & Std. Error & & & \\
\hline \multirow{4}{*}{1} & (Constant) & 6,447 & ,633 & & 10,177 & ,000 \\
\hline & BOPO (X1) &,- 059 & ,007 &,- 616 & $-8,398$ & ,000 \\
\hline & CAR (X2) & ,009 &, 004 & ,178 & 2,329 & ,022 \\
\hline & QR (X3) &,- 004 &, 002 &,- 121 & $-1,650$ & ,102 \\
\hline
\end{tabular}

a. Dependent Variable: ROA (Y)

Sumber: data sekunder diolah

Dalam penelitian ini rumus persamaan regresi berganda adalah sebagai berikut:

$$
Y=-0,616 X 1+0,178 X 2-0,121 X 3+e 1
$$

Berdasarkan persamaan regresi linear berganda diatas, maka dapat di interprestasikan sebagai berikut (i) koefisien regresi X1 (BOPO) dari perhitungan linier berganda terdapat nilai sebesar -0,616, hal ini berarti apabila variabel independen lainnya tetap, maka setiap ada peningkatan satu persen variabel BOPO akan menyebabkan penurunan tingkat profitabilitas (ROA) sebesar 0,616 persen, (ii) koefisien regresi X2 (CAR) dari perhitungan linier berganda terdapat nilai sebesar 0.178, hal ini berarti apabila variabel lainnya tetap, maka setiap ada peningkatan satu persen variabel CAR maka tingkat Profitabilitas (ROA) akan naik sebesar 0.178 persen, (iii) Koefisien regresi X3 (QR) dari perhitungan linier berganda dapat dilihat $-0,121$, hal ini berarti apabila variabel independen lainnya tetap, maka setiap ada peningkatan satu persen variabel QR akan menyababkan penurunan tingkat Profitabilitas (ROA) sebesar 0,121 persen.

\section{Moderated Regression Analysis(MRA)}

Analisis ini bertujuan untuk mengetahui apakah ada hubungan antara Tingkat Kecukupan Modal (CAR) dan Likuidias (QR) dalam peningkatan atau penurunan Profitabilitas (ROA) pada bank umum syariah tahun 2011 - 2014 dengan variabel Likuiditas (QR) sebagai penguat atau pelemah. Pengolahan data menggunakan bantuan program komputer IBM SPSS versi 21.00. Berdasarkan data-data yang diperoleh dari laporan keuangan.

Tabel 20. Uji Hipotesis Substruktur 2 tahap 1 Coefficients ${ }^{\text {a }}$ CAR melalui QR

\begin{tabular}{lrrrrrr}
\hline \hline Model & $\begin{array}{c}\text { Unstandardized } \\
\text { Coefficients }\end{array}$ & $\begin{array}{c}\text { Standardiz } \\
\text { ed } \\
\text { Coefficient } \\
\end{array}$ & & T & Sig. \\
\cline { 2 - 6 } 1 & B & Std. Error & Beta & & \\
\hline \multirow{2}{*}{1} & (Constant) & 40,834 & 6,277 & & 6,506 &, 000 \\
\cline { 2 - 6 } & CAR (X2) &, 524 &, 162 &, 294 & 3,228 &, 002 \\
\hline
\end{tabular}

a. Dependent Variable: QR (X3)

Tabel 21. Uji Hipotesis Substruktur 2 tahap 2 Coefficients $^{\text {a }}$ QR terhadap ROA 


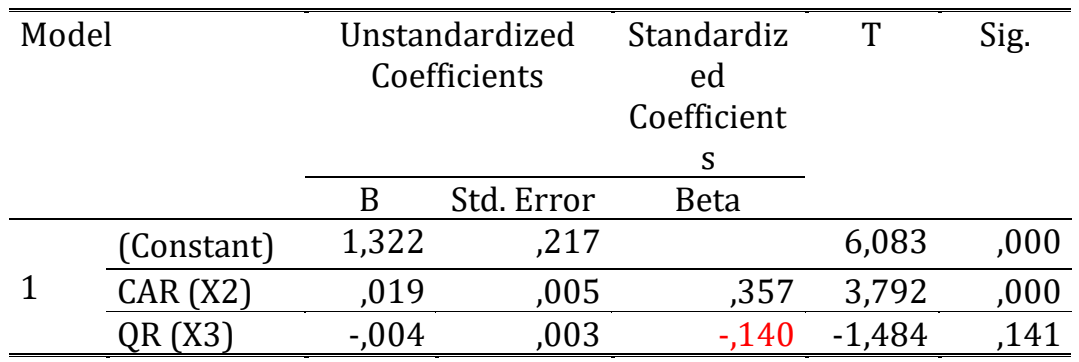

a. Dependent Variable: ROA (Y)

Sumber: Data Sekunder Diolah

Dalam penelitian ini rumus persamaan korelasi paerson adalah sebagai berikut:

$$
Y=0,294 X 2-0,140 X 3+e 2
$$

Berdasarkan persamaan diatas, maka dapat di interprestasikan yaitu (i) koefisien korelasi X2 (CAR) terhadap X3 (QR) dari perhitungan linier sederhana terdapat nilai sebesar 0,294, hal ini berarti apabila ada peningkatan satu persen variabel CAR akan menyebabkan kenaikan tingkat Likuiditas (QR) sebesar 0,294 persen, (ii) koefisien korelasi X3 (QR) terhadap Y (ROA) dari perhitungan korelasi bivariate terdapat nilai sebesar $-0,140$, hal ini berarti apabila ada peningkatan satu persen variabel QR akan menyebabkan penurunan tingkat profitabilitas (ROA) sebesar 0,140 persen, (iii) koefisien korelasi X2 (CAR) terhadap Y (ROA) melalui X3 (QR) dari perhitungan linier sederhana dan korelasi bivariate tedapat pengaruh total senilai 0,154 persen $(0,294-0,140)$ dengan pengaruh tidak langsung sebesar $-0,04116$ persen, hal ini berarti apabila ada peningkatan satu persen variabel QR akan menyebabkan pelemahan pengaruh variabel CAR terhadap tingkat Profitabilitas (ROA) sebesar 0,154 persen.

\section{Analisis Korelasi Bivariate}

Analisis ini digunakan untuk menafsirkan angka korelasi antar variabel yang diperoleh berdasarkan perhitungan SPSS dengan menggunakan angka 0,01 karena hasil perhitungan SPSS memberikan angka signifikansi sebesar 0,01 yang ditandai dengan dua bintang (**). Standar SPSS antara 0,01 sampai dengan 0,05 .

Tabel 22. Correlations Variabel BOPO, CAR, dan QR terhadap ROA

\begin{tabular}{llccc}
\hline \hline & & BOPO (X1) & CAR (X2) & QR (X3) \\
\hline \multirow{3}{*}{ B0PO (X1) } & $\begin{array}{l}\text { Pearson } \\
\text { Correlation }\end{array}$ & 1 &,$- 282^{* *}$ &,- 056 \\
\cline { 2 - 5 } & Sig. (2-tailed) & &, 003 &, 559 \\
\cline { 2 - 5 } & $\mathrm{N}$ & 112 & 112 & 112 \\
\hline \multirow{3}{*}{ CAR (X2) } & Pearson &,$- 282^{* *}$ & 1 &, $294^{* *}$ \\
\cline { 2 - 5 } & Correlation & & & \\
\cline { 2 - 5 } & Sig. (2-tailed) &, 003 & &, 002 \\
\hline \multirow{3}{*}{ QR (X3) } & Pearson & 112 & 112 & 112 \\
\cline { 2 - 5 } & Correlation &,- 056 &, $294^{* *}$ & 1 \\
\cline { 2 - 5 } & Sig. (2-tailed) & & & \\
\cline { 2 - 5 } & $\mathrm{N}$ & 112 & 112 & 112 \\
\hline \hline
\end{tabular}

**. Correlation is significant at the 0.01 level (2-tailed).

Korelasi antara BOPO dan CAR menunjukkan angka sebasar -0,282 artinya hubungan antara BOPO dan CAR adalah cukup kuat dan berlawanan arah (karena hasilnya negatif). Berlawanan arah artinya jika 
Penggunaan Path Analysis Dalam Analisis.....

nilai BOPO tinggi maka CAR akan mengalami penurunan begitupun sebaliknya. Korelasi dua variabel bersifat signifikan karena angka signifikansi (sig) $<0,01$.

Korelasi antara BOPO dan QR menunjukkan angka sebesar -0,056 artinya hubungan antara BOPO dan QR adalah sangat lemah dan berlawanan arah (karena hasilnya negatif). Berlawanan arah artinya jika nilai BOPO tinggi maka QR akan mengalami penurunan begitupun sebaliknya. Korelasi dua variabel bersifat tidak signifikan karena angka signifikansi 0,559>0,01.

Tabel 23. Correlations variabel CAR dan QR terhadap ROA

\begin{tabular}{llrr}
\hline & & CAR (X2) & QR (X3) \\
\hline \multirow{2}{*}{ CAR (X2) } & Pearson Correlation & 1 &, $294^{* *}$ \\
\cline { 2 - 4 } & Sig. (2-tailed) & 112 &, 002 \\
\cline { 2 - 4 } & $\mathrm{N}$ &, $294^{* *}$ & 112 \\
\hline \multirow{3}{*}{ QR (X3) } & Pearson Correlation &, 002 & 1 \\
\cline { 2 - 4 } & Sig. (2-tailed) & 112 & 112 \\
\cline { 2 - 4 } & $\mathrm{N}$ &
\end{tabular}

**. Correlation is significant at the 0.01 level (2-tailed).

Korelasi antara CAR dan QR menunjukkan angka sebesar 0,294 artinya hubungan antara CAR dan QR adalah cukup kuat dan searah (karena hasilnya positif). searah artinya jika nilai CAR tinggi maka QR juga tinggi. Korelasi dua variabel bersifat signifikan karena angka signifikansi 0,002<0,01

\section{Uji Signifikansi Parameter Individual (Uji Statistik t)}

Dari hasil analisis regresi output dapat disajikan sebagai berikut:

Tabel 24. Uji T Persamaan Substruktur 1

Coefficients $^{\mathbf{a}}$

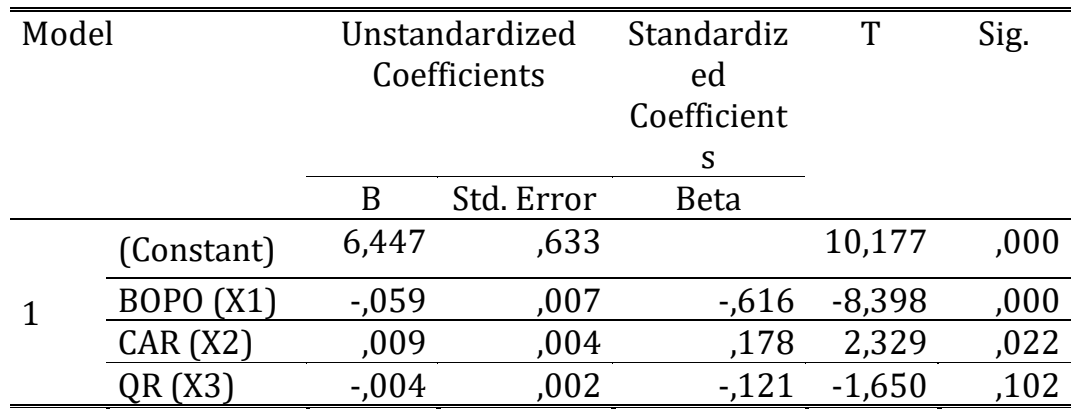

a. Dependent Variable: ROA (Y)

Sumber: Data Sekunder Diolah

Dari tabel diatas diketahui bahwa (i) uji parsial untuk variabel X1 (BOPO) di peroleh $t$ hitung sebesar 0,398, dengan signifikasi 0,000 (kurang dari 0,05). Sedangkan $t_{\text {tabel }}$ dengan $\mathrm{df}=(\mathrm{n}-\mathrm{k}-1)$ atau $112-3-1=$ 108 adalah sebesar 1,982. Sehingga- $\mathrm{t}_{\text {hitung }}<\mathrm{t}_{\text {tabel }}=-0,398<1,982$. Maka dapat disimpulkan bahwa H0 di tolak dan H1 diterima, yaitu Efisiensi Operasional (BOPO) berpengaruh secara signifikan terhadap profitabilitas (ROA) Bank Umun Syariah, (ii) uji parsial untuk variabel X2 (CAR) di peroleh t hitung sebesar 2,329, dengan singnifikasi 0,022 (kurang dari 0,05). Sedangkan $t$ tabel dengan df = 112-3-1=108 adalah sebesar 1,982. sehingga $t_{\text {hitung }}>t$ tabel $=2,329>1,982$. Maka dapat disimpulkan bahwa H0 di tolak dan H2 diterima, yaitu Tingkat Kecukupan Modal (CAR) berpengaruh secara signifikan terhadap profitabilitas (ROA) Bank Umun Syariah, (iii) uji parsial untuk variabel X3 (QR) di peroleh t hitung sebesar - 
1,650, dengan singnifikasi 0,102 (lebih dari 0,05). Sedangkan $t$ tabel dengan $\mathrm{df}=112-3-1=108$ adalah sebesar 1,982. sehingga $-\mathrm{t}_{\text {hitung }}<\mathrm{t}_{\text {tabel }}=-1,650<1,982$. Maka dapat disimpulkan bahwa H0 diterima dan H3 ditolak, yaitu Likuiditas (QR) tidak terbukti berpengaruh secara signifikan terhadap profitabilitas (ROA) Bank Umun Syariah.

\section{Uji Signifikansi Simultan (Uji Statistik F)}

Dari hasil output analisis regresi dapat diketahui nilai F seperti pada tabel berikut ini:

Tabel 25. Uji F Persamaan Substruktur 1

ANOVA $^{a}$

\begin{tabular}{llrrrrr}
\hline Model & $\begin{array}{c}\text { Sum of } \\
\text { Squares }\end{array}$ & Df & \multicolumn{1}{c}{$\begin{array}{c}\text { Mean } \\
\text { Square }\end{array}$} & F & Sig. \\
\hline \multirow{3}{*}{1} & Regression & 84,438 & 3 & 28,146 & 31,443 &, $000^{\mathrm{b}}$ \\
\cline { 2 - 8 } & Residual & 96,676 & 108 &, 895 & & \\
\cline { 2 - 8 } & Total & 181,115 & 111 & & & \\
\hline \hline
\end{tabular}

a. Dependent Variable: ROA (Y)

b. Predictors: (Constant), QR (X3), BOPO (X1), CAR (X2)

Sumber: Data Sekunder Diolah

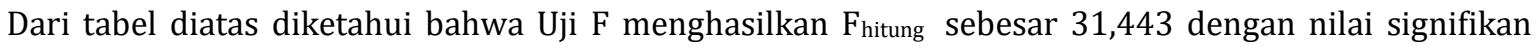
sebesar 0,000 (kurang dari 0,05). Sedangkan $\mathrm{F}$ tabel dengan menggunakan tingkat keyakinan 95\%, $\alpha=$ $5 \%$, df $1(4-1)=3$, dan df $2(n-k-1)$ atau 112-3-1 = 108 adalah sebesar 2,688. sehingga $F$ hitung $>F_{\text {tabel }}=$ 31,443 > 2,688. Maka dapat disimpulkan bahwa Efisiensi Operasional (BOPO), Tingkat Kecukupan Modal (CAR), dan Likuiditas (QR) bersama sama berpengaruh secara signifikan terhadap Profitabilitas (ROA) Bank Umun Syariah.

\section{Koefisien Determinasi $\left(\mathbf{R}^{2}\right)$}

Analisis determinasi dalam regresi linear berganda digunakan untuk mengetahui prosentase sumbangan pengaruh variabel independen $(\mathrm{X} 1, \mathrm{X} 2, \ldots \ldots \mathrm{Xn})$ secara serentak terhadap variabel dependen (Y). Koefisien ini menunjukkan seberapa besar prosentase variasi variabel independen yang digunakan dalam model mampu menjelaskan variasi variabel dependen. $\mathrm{R}^{2}$ sama dengan 0 , maka tidak ada sedikitpun prosentase sumbangan pengaruh yang diberikan variabel independen terhadap variabel dependen, atau variasi variabel independen yang digunakan dalam model tidak menjelaskan sedikitpun variasi variabel dependen. Sebaliknya $\mathrm{R}^{2}$ sama dengan 1 , maka prosentase sumbangan pengaruh yang diberikan variabel independen terhadap variabel dependen adalah sempurna, atau variasi variabel independen yang digunakan dalam model menjelaskan 100\% variasi variabel dependen.

Tabel 26. Uji Koefisien Determinasi Persamaan Substruktur 1 Model Summary

\begin{tabular}{lccrr}
\hline \hline Model & $\mathrm{R}$ & R Square & $\begin{array}{c}\text { Adjusted R } \\
\text { Square }\end{array}$ & $\begin{array}{c}\text { Std. Error of the } \\
\text { Estimate }\end{array}$ \\
\hline 1 &, $683^{\mathrm{a}}$ &, 466 &, 451 &, 94612 \\
\hline a. Predictors: (Constant), QR (X3), BOPO (X1), CAR (X2) & \\
\multicolumn{4}{c}{ Sumber: Data Sekunder Diolah }
\end{tabular}

Pada persamaan substruktur 1 terdapat tiga variabel independen (lebih dari 2) maka untuk menguji Koefisien Determinasinya menggunakan Adjusted $R$ Square, yaitu nilai $R$ Square yang telah 
Penggunaan Path Analysis Dalam Analisis.....

disesuaikan, nilai ini selalu lebih kecil dari $R$ Square dan angka ini bisa memiliki harga negatif. Menurut Santoso (2001) bahwa untuk regresi dengan lebih dari dua variabel bebas digunakan Adjusted $R^{2}$ sebagai Koefisien Determinasi.

Dari tabel diatas dapat diketahui bahwa angka Adjusted $\mathrm{R}^{2}$ (Ajusted $R$ Square) sebesar 0,451 atau $(45,1 \%)$. Hal ini menunjukkan bahwa prosentase sumbangan pengaruh variabel independen (BOPO, CAR dan $Q R$ ) terhadap variabel dependen (ROA) sebesar 45,1\%. Atau variasi variabel independen yang digunakan dalam model (BOPO, CAR dan QR) mampu menjelaskan sebesar 45,1\% variasi variabel dependen (ROA). Sedangkan sisanya sebesar 54,9\% dipengaruhi atau dijelaskan oleh variabel lain yang tidak dimasukkan dalam model penelitian ini.

Standard Error of the Estimate adalah suatu ukuran banyaknya kesalahan model regresi dalam memprediksikan nilai Y. Dari hasil regresi di dapat nilai 0,94612 atau 0,94612\% (satuan Profitabilitas), hal ini berarti banyaknya kesalahan dalam prediksi Profitabilitas sebesar 0,94612\%. Sebagai pedoman jika Standard error of the estimate kurang dari standar deviasi Y, maka model regresi semakin baik dalam memprediksi nilai Y.

\section{Analisis Korelasi Ganda (R)}

Tabel 27. Hasil MRA Variabel CAR dan QR Model Summary

\begin{tabular}{|c|c|c|c|c|}
\hline Model & R & R Squa & $\begin{array}{r}\text { Adjusted } \\
\text { Square }\end{array}$ & $\begin{array}{l}\text { Std. Error of the } \\
\text { Estimate }\end{array}$ \\
\hline
\end{tabular}

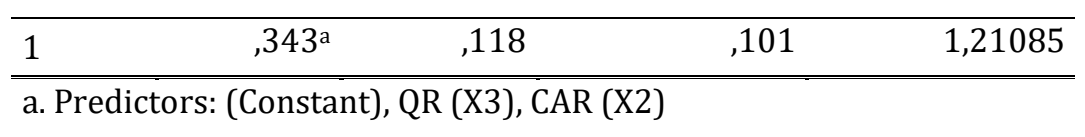

Sumber: Data Sekunder Diolah

Berdasarkan tabel diatas diperoleh angka $\mathrm{R}$ sebesar 0,343. Hal ini menunjukkan bahwa terjadi hubungan yang rendah antara variabel CAR dengan variabel QR.

\section{PEMBAHASAN}

\section{Pengaruh Efisiensi Operasional (BOPO) Terhadap Profitabilitas (ROA) Bank Umum Syariah}

Berdasarkan pada teori, semakin Tinggi Efisiensi Operasional (BOPO) maka semakin rendah Profitabilitas (ROA). Hal ini menunjukkan bahwa terdapat hubungan yang negatif antara BOPO dan ROA. Berdasarkan hasil analisis regresi linear berganda dapat diketahui bahwa variabel Efisiensi Operasional (BOPO) (X1) menunjukkan bahwa terdapat pengaruh yang negatif dan signifikan terhadap Profitabilitas (ROA) (Y) pada Bank Umum Syariah di Indonesia tahun 2011-2014 sebesar -0,616 dengan tingkat signifikansi 0,000. Hasil ini konsisten dengan penelitian yang dilakukan oleh Edhi Satrio Wibowo dan Muhammad Syaichu (2013) yang menyatakan bahwa BOPO memiliki pengaruh yang signifikan negatif terhadap ROA. Jika biaya operasional semakin meningkat tetapi tidak diimbangi/dibarengi dengan pendapatan operasional maka akan mengakibatkan berkurangnya ROA. Penelitian ini juga memperkuat hasil penelitian yang dilakukan oleh Yuliani (2007) dan Dewi Inaroh (2014) yang menyatakan bahwa terdapat pengaruh yang signifikan antara BOPO terhadap ROA. 


\section{Pengaruh Kecukupan Modal (CAR) Terhadap Profitabilitas (ROA) Bank Umum Syariah}

Berdasarkan pada teori, semakin tinggi Tingkat Kecukupan Modal (CAR) maka semakin tinggi pula Profitabilitas (ROA). Hal ini menunjukkan bahwa terdapat hubungan yang positif antara CAR dan ROA. Berdasarkan hasil analisis regresi linear berganda dapat diketahui bahwa variabel Tingkat Kecukupan Modal (CAR) (X2) menunjukkan bahwa terdapat pengaruh yang positif dan signifikan terhadap Profitabilitas (ROA) (Y) pada Bank Umum Syariah di Indonesia tahun 2011-2014 sebesar 0,178 dengan tingkat signifikansi 0,022. Penelitian ini memperkuat hasil penelitian yang dilakukan oleh Yuliani (2007) yang menyatakan bahwa CAR berpengaruh signifikan terhadap ROA. Akan tetapi penelitian ini bertentangan dengan penelitian yang dilakukan oleh Edhi Satrio Wibowo dan Muhammad Syaichu (2013), serta Dewi Inaroh (2014) yang menyatakan bahwa CAR tidak memiliki pengaruh yang signifikan terhadap ROA.

\section{Pengaruh Likuiditas (QR) Terhadap Profitabilitas (ROA) Bank Umum Syariah}

Berdasarkan pada teori, semakin tinggi Likuiditas (QR) dapat berpengaruh secara positif maupun negatif terhadap Profitabilitas (ROA). Hal ini menunjukkan bahwa Likuiditas (QR) dapat melahirkan hubungan yang positif maupun negatif terhadap Profitabilitas (ROA).

Berdasarkan hasil analisis regresi linear berganda dapat diketahui bahwa variabel Likuiditas (QR) (X3) menunjukkan bahwa terdapat pengaruh yang negatif dan tidak signifikan terhadap Profitabilitas (ROA) (Y) pada Bank Umum Syariah di Indonesia tahun 2011-2014 sebesar -0,121 dengan tingkat signifikansi 0,102 .

Penelitian ini memperkuat hasil penelitian yang dilakukan oleh Nur Fadhila (2009) yang menyatakan bahwa variabel likuiditas tidak terbukti berpengaruh terhadap profitabilitas. Serta mendukung hasil penelitian yang dilakukan oleh Rimski (2002) yang menyatakan bahwa semakin banyak dana yang menganggur berarti pemasaran uang tidak maksimal dan akhirnya bank tidak bisa memaksimalkan keuntungannya. Akan tetapi penelitian ini bertentangan dengan hasil penelitian yang dilakukan oleh Nidya Afirinda (2012) dan Gemi Ruwanti (2011) yang menyatakan QR berpengaruh positif dan signifikan terhadap ROA.

Pengaruh Kecukupan Modal (CAR) Terhadap Profitabilitas (ROA) Bank Umum Syariah Melalui

\section{Likuiditas (QR)}

Berdasarkan pada teori, semakin tinggi Tingkat Kecukupan Modal (CAR) maka semakin tinggi pula Likuiditas (QR). Akan tetapi semakin tinggi Likuiditas (QR) belum tentu Profitabilitas semakin tinggi. Hal ini menunjukkan bahwa Likuiditas $(\mathrm{QR})$ dapat pemperkuat atau memperlemah hubungan antara tingkat kecukupan modal terhadap Profitabilitas (ROA).

Berdasarkan hasil analisis korelasi bivariate, dapat diketahui bahwa variabel Tingkat Kecukupan Modal (CAR) (X2) melalui variabel Likuiditas (QR) (X3) menunjukkan terdapat pengaruh yang positif dan melemahkan terhadap Profitabilitas (ROA) (Y) pada Bank Umum Syariah di Indonesia tahun 2011-2014 sebesar 0,154 persen dengan prosentase pelemahan sebesar 0,024 dibandingkan dengan pengaruh langsung antara variabel Tingkat Kecukupan Modal (CAR) terhadap Profitabilitas (ROA) (Y) pada Bank Umum Syariah di Indonesia tahun 2011-2014 sebesar yang semula sebesar 0,178 persen. Dalam menguji 
pengaruh CAR terhadap ROA melalui QR peneliti belum menemukan hasil penelitian yang dapat mendukung atau hasil penelitian yang bertentangan dengan hasil penelitian ini

\section{KESIMPULAN}

Berdasarkan hasil penelitian, pengolahan data dan pembahasan pada Bab IV dapat ditarik kesimpulan bahwa (i) terdapat pengaruh yang negatif dan signifikan antara Efisiensi Operasional (BOPO) terhadap Profitabilitas (ROA) Bank Umum Syariah, (ii) terdapat pengaruh yang positif dan signifikan antara Tingkat Kecukupan Modal (CAR) terhadap Profitabilitas (ROA) Bank Umum Syariah, (iii) terdapat pengaruh yang negatif dan tidak sifnifikan antara Likuiditas (QR) terhadap Profitabilitas (ROA) Bank Umum Syariah, (iv) terdapat pengaruh yang positif dan dilemahkan antara Tingkat Kecukupan Modal (CAR) terhadap Profitabilitas (ROA) melalui Likuiditas (QR) Bank Umum Syariah.

\section{SARAN}

Berdasarkan hasil penelitian yang diperoleh maka saran yang dapat disampaikan adalah bagi penelitian selanjutnya adalah (i) disarankan agar menambah atau memperbanyak sampel penelitian dan memperpanjang periode penelitiannya, (ii) sebaiknya pada penelitian selanjutnya perlu menambah variabel independen lain karena sangat dimungkinkan rasio keuangan lain yang tidak dimasukkan dalam penelitian ini berpengaruh terhadap profitabilitas, (iii) penelitian selanjutnya diharapkan menggunakan metode dan alat uji yang lebih lengkap dan akurat sehingga diperoleh hasil yang lebih valid. Implikasi praktis bagi bank syariah disarankan bagi manajemen perbankan syariah agar lebih meningkatkan Efisiensi operasional, memaksimalkan Tingkat Kecukupan Modal, serta memproporsionalkan tingkat Likuiditasagar profitabilitas (laba) semakin meningkat.

\section{DAFTAR PUSTAKA}

Abbas, M. (t.thn.). Modul Short Course bank Syariah : Sistem Operasional Bank Syariah . Yogyakarta: Sekolah Tinggi Ekonomi islam.

Andryani Isna K dan Kunti Sunaryo. (t.thn.). Analisis Pengaruh Return On Asset, Bopo, Dan Suku Bunga Terhadap Tingkat Bagi Hasil Deposito Mudharabah Pada Bank Umum Syariah. Jurnal Ekonomi Dan Bisnis (JEBI),Volume 11. Nomor 01, 33-34.

Antonio, M. S. 2001. Bank Syari'ah Dari Teori Ke Praktek. Jakarta: Gema Insani Press.

Anwar Sanusi. 2011. Metode Penelitian Bisnis. Jakarta: Salemba Empat.

Arifin, Z. 2003. Dasar - Dasar Manajemen Bank Syariah. Jakarta: Alvabet.

Defri. (t.thn.). Pengaruh Capital Adequacy Ratio (CAR), Likuiditas dan Efisiensi Operasional Terhadap Profitabilitas Perusahaan Perbankan yang Terdaftar di BEI. Jurnal Manajemen, Volume 01, Nomor 01.

Edhi Satriyo Wibowo dan Muhammad Syaichu. 2013. Analisis Pengaruh Suku Bunga, Inflasi CAR, BOPO, NPF Terhadap Profitabilitas bank Syariah. Diponegoro Journal Of Management.

Harahap, S. 2002. Analisa Kritis Atas Laporan Keuangan. Jakarta: PT. Raja Grafindo Persada.

Judisseno, R. K. 2002. Sistem Moneter dan Perbankan di Indonesia. Jakarta: PT. Gramedia Pustaka Utama.

Kasmir. 2002. Manajemen Perbankan. Jakarta: PT. Raja Grafindo Persada. 
Kasmir. 2008. Analisis Laporan Keuangan. Jakarta: PT. Raja Grafindo Persada.

Mamduh M. Hanafi dan Abdul Halim. 2009. Analisis Laporan Keuangan. Yogyakarta: UPP STIM YKPN.

Muhamad. (t.thn.). Modul Short Course Bank Syariah. Yogyakarta: Pusat Studi ekonomi Islam STEI Yogyakarta.

Muhammad. 2005. Manajemen Bank Syariah. Yogyakarta: UPP AMP YKPN.

Muhammad. 2005. Manajemen Pembiayaan Bank Syariah. Yogyakarta: UPP AMP YKPN.

Musyaroftun, L. D. 2012. Analisis Faktor-faktor yang mempengaruhi Rentabilitas Bank Perkreditan Rakyat Di Kabupaten Magelang. Accounting Analysis Journal, Vol. I, No. 3.

Noor, J. 2011. Metodologi Penelitian Skripsi, Tesis, Disertasi,dan Karya Ilmiah, Edisi Pertama. Jakarta: Kencana.

Pramuka, B. A. (t.thn.). Faktor-Faktor Yang Berpengaruh Terhadap Tingkat Profitabilitas Bank Umum Syariah. urnal Akuntansi, Manajemen Bisnis Dan Sektor Publik (JAMBSP) ISSN 1829 - 9857.

Rifai, M. 2002. Konsep Perbankan Syari'ah. Semarang: CV. Wicaksana.

Sarwono, J. 2007. Analisis Jalur Untuk Riset bisnis dengan SPSS. Yogyakarta: Andi.

Soemitra, A. 2009. Bank dan Lembaga Keuangan Syariah. Jakarta: Kencana.

Sudarsono, H. 2003. Bank dan Lembaga Keuangan Syariah, Edisi II. Yogyakarta: Ekonisia.

Sugiyono. 2012. Metode Penelitian Pendidikan Pendekatan Kuantitatif, Kualitatif, dan R\&D, Cet. 16. Bandung: Alfabeta.

Sumitro, W. 1996. Asas-Asas Perbankan Islam dan Lembaga-Lembaga Terkait (BMUI \& TAKAFUL) di Indonesia. Jakarta: PT. Raja Grafindo Persada.

Taswan. 2010. Manajemen Perbankan (Konsep, Teknis, \& Aplikasi), Edisi II. Yogyakarta: UPP STIM YKPN.

Totok Budi Santoso dan Sigit Triandaru. 2006. Bank dan Lembaga Keuangan Lain. Jakarta: Salemba Empat.

Usman, R. 2009. Produk dan Akad Perbankan Syariah di Indonesia. Bandung: PT. Citra Aditya Bakti.

Veithzal Rivai dan Arvian Arifin. 2010. Islamic Banking Sistem Bank Islam Bukan Hanya Solusi Menghadapi Krisis Namun Solusi dalam Menghadapi Berbagai Persoalan Perbankan \& Ekonomi Global Sebuah Teori, Konsep, dan Aplikasi. Jakarta: Bumi Aksara.

Yuliani. 2007. Hubungan Efisieni Operasional dengan Kinerja Profitabilitas Pada Sektor Perbankan yang Go Publik Di Bursa Efek Jakarta. Jurnal manajemen \& Bisnis Sriwijaya, Vol. V No. 10. 